\title{
Subduction Polarity in Ancient Arcs: A Call to Integrate Geology and Geophysics to Decipher the Mesozoic Tectonic History of the Northern Cordillera of North America: REPLY
}

\author{
Terry L. Pavlis, Dept. of Geological Sciences, University of Texas, El Paso, Texas 79968, USA; Jeffrey M. Amato, Dept. of Geological \\ Sciences, New Mexico State University, Las Cruces, New Mexico 88003, USA; Jeffrey M. Trop, Dept. of Geology and Environmental \\ Geosciences, Bucknell University, Lewisburg, Pennsylvania 17837, USA; Kenneth D. Ridgway, Dept. of Earth, Atmospheric and Planetary \\ Sciences, Purdue University, West Lafayette, Indiana 47907, USA; Sarah M. Roeske, Earth and Planetary Sciences Dept., University of \\ California, Davis, California 95616, USA; and George E. Gehrels, Dept. of Geosciences, University of Arizona, Tucson, Arizona, 85721, USA
}

\section{INTRODUCTION}

We welcome the opportunity to discuss the views expressed by Sigloch and Mihalynuk in their Comment (Sigloch and Mihalynuk, 2020; referred to here as SM) on Pavlis et al. (2019) because it provides an opportunity to elaborate on the criteria for determining subduction polarity, an important problem in the North American Cordillera and for tectonic reconstructions in general. However, we believe SM have disregarded extensive geologic data in an attempt to support their model, underscoring our original point that tectonic models need to accommodate geologic observations. We suggest that their perspective arises from two assumptions: (1) that the geophysically imaged slab walls indicate ancient trench position; and (2) that because plate reconstructions place North America east of imaged slab walls, North America must have been east of the trench. From these assumptions they subsequently disregard, or attempt to explain away, key geologic relationships countering this model. However, it is only a model, and some of their dismissal of existing data apparently comes from a misunderstanding of geologic relationships and, importantly, the timing of these relationships. We readily acknowledge some of the ambiguities in the geologic record, but any integrated model must address the available observations. Disparate views of five key relationships are discussed in this paper.

\section{INTERPRETATION OF DEEP \\ MANTLE TOMOGRAPHIC \\ ANOMALIES AND PLATE RECONSTRUCTION}

This topic is a key part of the story, and we devoted several pages to this issue in early drafts of the paper. However, when we realized that experts in this field were actively debating the topic, we reduced our discussion to a short paragraph. In their Comment, SM reiterate parts of their model but emphasize a consensus in the geophysical community that deep mantle tomographic anomalies are subduction zone remnants. We agree there is a consensus that some upper-mantle anomalies can be tracked up to existing subducting slabs and locally lower-mantle anomalies exist and can appear to be continuous with upper mantle anomalies. However, we disagree with extending that statement to the interpretation of what the deep anomalies represent and, in particular, their relationship to the positions of ancient subduction zones. As we noted in our original paper (Pavlis et al., 2019), interpretations of the tomographic images presented in Sigloch and Mihalynuk $(2013,2017)$ have been the subject of debate (e.g., Liu, 2014; Sun et al., 2017). We have concerns that the caveats expressed by Foulger et al. (2013) about the interpretation of tomographic images have not been adequately addressed by the geophysics community. Molnar (2019) reviewed results from mantle convection models, tomographic models, and mantle evolution models and concluded that wholemantle convection models are almost certainly wrong. He instead argued for a revision of two-layered convection with a lower-upper mantle boundary in the depth range of 1000-1500 km. The importance of these models is clear in the context of this discussion; if Molnar (2019) is correct, using deep-mantle anomalies to constrain plate motion is meaningless, and this entire discussion is moot. Thus, the deep mantle problem is not solved, which underscores our conclusion that resolving ancient subduction polarity problems requires a concerted collaborative effort between the geologic and geophysical communities.

A foundation of Sigloch and Mihalynuk's (2013, 2017) interpretations is that plate reconstructions restore North America to a position too far east for a continuous eastdipping subduction system to generate the deep anomaly. We suggest this reasoning has two pitfalls: (1) plate reconstructions for the Cenozoic are well-constrained, but it becomes increasingly suspect in deeper time because of difficulties with relative hot spot motions (e.g., Tarduno et al., 2009); and (2) if the margin was not strictly Andean, east-dipping subduction in an offshore arc system could equally well have produced the anomaly if the ocean basin was large enough. Note that we agree with SM that in our paper the argument using plate reconstructions of van de Meer et al. (2010) involved somewhat circular reasoning, but conceding this point does not eliminate either of these serious pitfalls.

\section{TIME ISSUES}

In their Comment, SM call on tectonic events that are reasonable but infer that the events occurred at times inconsistent with published geologic data. This was, in fact, one of our greatest concerns with the SM model and the "ribbon continent" models we cited (e.g., Johnston, 2008). There are several examples, but here we cite two.

First, west-dipping subduction with a colliding arc is not a new concept for Cordilleran tectonics (as SM noted), nor is the concept of a Mesozoic archipelago analogous to

GSA Today, v. 30, https://doi.org/10.1130/GSATG465Y.1. Copyright 2020, The Geological Society of America, CC-BY-NC. 
the southwest Pacific (e.g., Silver and Smith, 1983; Blakey and Ranney, 2018). The problem is where and when west-dipping subduction occurred. SM argue for long-lived, continuous, west-directed subduction that would still be active in the Late Cretaceous (SM, their fig. 1A), but no geologic evidence for this polarity exists beneath the Wrangellia Composite/Insular (WCT/INS) belt and none exists beneath the Intermontane/YukonTanana that is younger than early Jurassic (and even that is debated; e.g., compare Dusel-Bacon et al., 2015, with Mihalynuk et al., 1994). There is abundant evidence for a Permian arc collision that involved west-dipping subduction (e.g., closure of the Slide Mountain ocean; Dusel-Bacon et al., 2006; Beranek and Mortensen, 2011) and our Figure 1A (a more accurate version of Pavlis et al., 2019, fig. 1A) shows the Brooks Range in northern Alaska forming via outward (away from continent) subduction-collision with an arc. However, the timing of this event is significantly older than closure of the ocean basin between the WCT/INS belt and North America, and no continuity exists between arcs of the WCT/INS and those recording closure of the Angayucham Ocean. Thus, we show these as separate subduction systems.

A second example is the statement in SM's Comment that we prefer an "always-Andean" model; this misrepresents our view of the Cordillera over time. An Andean analog for the Cordillera margin during latest Cretaceous to late Eocene time is well documented since the early days of plate tectonics (e.g., Coney, 1978; Coney and Evenchick, 1994), but few, if any, would make that analogy for any time prior to ca. $80 \mathrm{Ma}$ at latitudes north of $\sim 42^{\circ}$. Since the first paleomagnetic data published from late Triassic rocks in Wrangellia (Hillhouse, 1977) and early terrane syntheses (e.g., Coney et al., 1980), it has been clear that at least some parts of the WCT/INS originated far from its present position. Interpretations of the path the composite terrane took, the width of the ocean basin between it and NA in Jurassic time, and how it became dispersed along the margin are interpretations that continue to evolve (e.g., Miller et al., 2006; Matthews et al., 2017). The polarity of subduction that closed the Mesozoic ocean basin, however, is not as contentious as SM claim.

\section{WESTERN MARGIN OF WCT/INS: EVIDENCE FOR PERSISTENT EAST- DIPPING SUBDUCTION}

We are puzzled by the statement in SM that "our Archipelago model features as much eastward subduction as the Andean-style model, just located further west" and that Figure 1 in Pavlis et al. (2019) misrepresents SM's portrayal of this eastward subduction zone. Although Sigloch and Mihalynuk (2013) show east-dipping subduction along a portion of WCT/INS in the Cretaceous, Figure $1 \mathrm{C}$ in Pavlis et al. (2019) is an accurate representation of Figure 4B of Sigloch and Mihalynuk (2017), which shows only west-dipping subduction along the inboard margin of WCT/ INS. Despite this confusion, however, even if they now accept eastward subduction west of WCT/INS, it is clear in Sigloch and Mihalynuk's (2017) original model that they rejected eastward subduction for this boundary over large swaths of geologic time.

The subduction polarity in southern Alaska was controversial in the past (e.g., Reed and Lanphere, 1974; Hudson, 1979; Reed et al., 1983; Wallace et al., 1989; Decker et al., 1994; Plafker and Berg, 1994), but the basis of the controversy has diminished as more data have accumulated. Most of us have worked on this problem from a variety of perspectives, including structural/petrologic studies, stratigraphic studies, and igneous/detrital geochronology. We admit there are ambiguities arising from an incomplete geologic record. Nonetheless, as we emphasized in our original paper, there is strong upper-plate geologic evidence for all of the elements of a seaward-facing (i.e., east-dipping) subduction system through all of Jurassic and Cretaceous time.

Despite disturbance by later events, this subduction geometry is now clearly recorded along the western margin of the WCT by the characteristic tripartite forearc-arc assemblage of accretionary prism (with blueschists), a long-lived forearc basin, and magmatic arc (Figs. 1 and 2; also fig. 2 in Pavlis et al., 2019). Gaps in the accretionary record, unconformities in the forearc basin, and gaps in the magmatic record reflect processes that complicate subduction margins, including ridge-subduction (e.g., Mahar et al., 2019), subduction erosion in the forearc (e.g., Clift et al., 2005; Amato et al., 2013), back-arc opening and closure, and complications from strike-slip (Pavlis and Roeske, 2007). In contrast to this rich record of subduction along the western margin of WCT/INS, nowhere have any geologic relations been observed that record west-dipping subduction beneath WCT/INS.

A fundamental difference between our interpretation of the rock record and that of $\mathrm{SM}$ is that they seem to require continuous accretion in the accretionary complex as evidence of continuous subduction. However, there is clear evidence globally that most arcs, particularly oceanic arcs like the Talkeetna arc, which forms part of the WCT/INS, undergo episodes of either subduction erosion or non-accretion (von Huene and Scholl, 1991; Clift and Vannucchi, 2004). The fact that the oldest part of the Talkeetna arc overlaps in age with the oldest blueschist facies metamorphic rocks on the oceanward (western) side of the arc (Fig. 2), and that blueschist facies rocks are preserved intermittently along strike for hundreds of kilometers and span $>20$ m.y. of crystallization ages, is a compelling case for the blueschists recording initiation and early stages of subduction beneath WCT/INS in the latest Triassicearly Jurassic (Roeske et al., 1989). As we stated in our original paper, the gap in time between the blueschist facies rocks and the more outboard part of the accretionary complex coincides very clearly with the migration of arc magmatism away from the trench (Fig. 2). Thus, we interpreted this preservation gap in the accretionary complex as resulting from subduction erosion (Amato et al., 2013). The next phase of accretion (Fig. 2) was a mélange with maximum depositional ages ranging from ca. 170-150 Ma (Amato et al., 2013), a second blueschist assemblage with a maximum depositional age (MDA) of ca. $135 \mathrm{Ma}$ (Day et al., 2016), syn-thrusting emplacement of forearc plutons at ca. 125 $\mathrm{Ma}$, and a second mélange assemblage with MDAs of ca. 100-90 Ma. The first mélange assemblage contains detrital zircons indicative of a source exclusively from the WCT/ INS, and the second mélange contains plutonic clasts with U-Pb zircon ages (199-179 Ma; Amato et al., 2013) that match the age of the Talkeetna arc (Amato et al., 2007) mixed with a North American source from what is now SE Alaska. Any gaps in the accretionary complex are filled by arc magmatism and sedimentary basin archives exposed upon the outboard part of the WCT/INS (Fig. 2; Clift et al., 2005; Rioux et al., 2007).

The Jurassic-Cretaceous sedimentary strata exposed between the Chugach accretionary complex and Jurassic-Cretaceous magmatic arc rocks within the WCT/INS are interpreted as west-facing forearc basins (Fig. 2). Like the adjacent accretionary complex, the forearc basin deposits yield detrital zircon signatures that match Jurassic-Cretaceous magmatic arc source terranes exposed within the WCT/INS (Trop et al., 2005; Reid et al., 2018; Stevens Goddard 

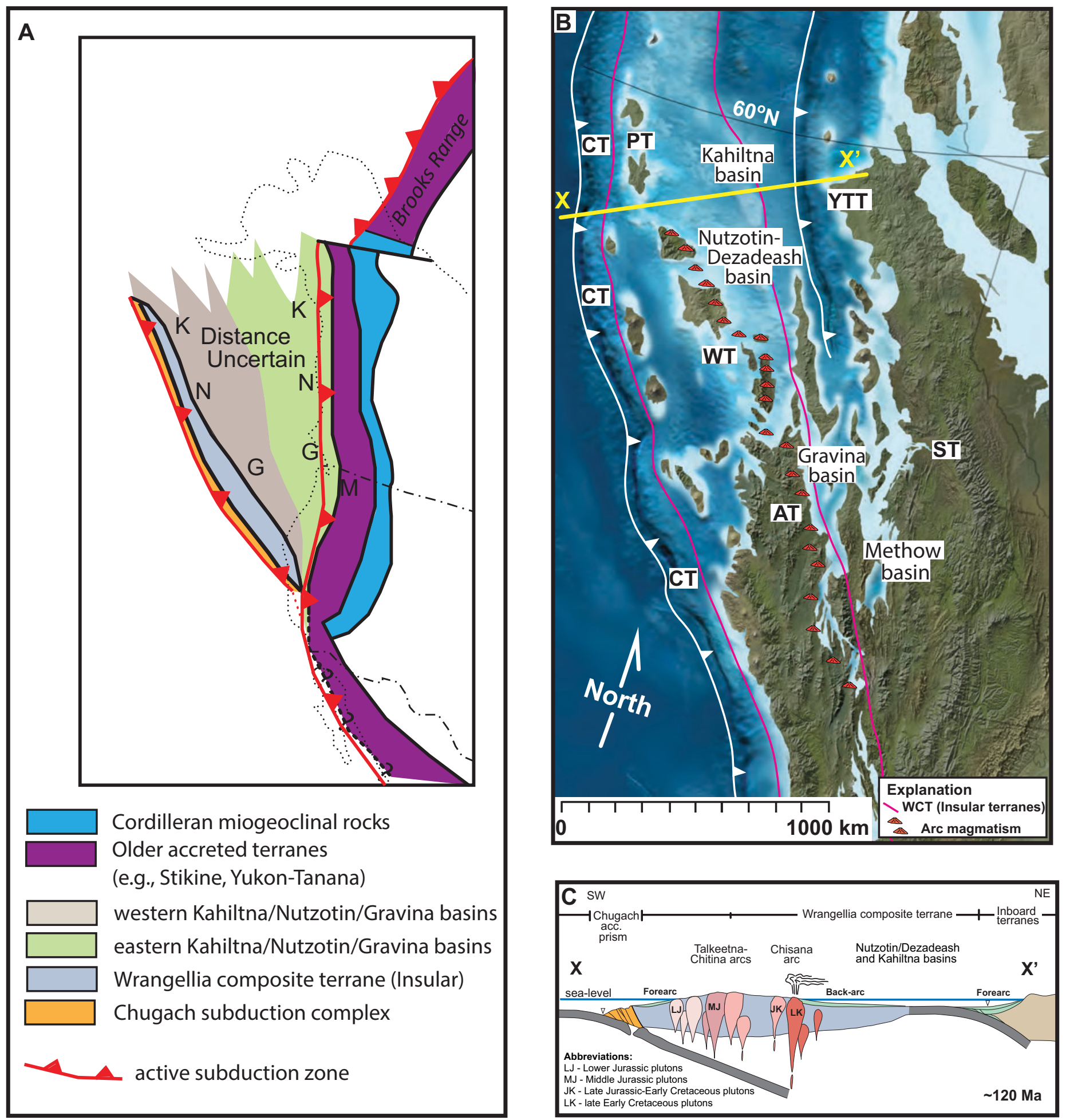

Figure 1. Schematic terrane map (A), paleogeographic map (B), and cross section (C) showing our preferred tectonic model of the northwestern Cordillera ca. 130 Ma with east-dipping subduction beneath Chugach subduction complex (CT) and Wrangellia composite terrane (WCT [also referred to as the Insular terrane] is outlined in red, and includes AT, PT, and WT), east-dipping subduction beneath inboard terranes, and a marine basin of indeterminate width separating the WCT from inboard terranes. Terrane abbreviations: AT-Alexander; CT-Chugach; PT-Peninsular; ST-Stikine; WT-Wrangellia; YTTYukon-Tanana. Abbreviations in A are G-Gravina basin; K-Kahiltna basin; M-Methow basin; N-Nutzotin basin. Spatial extent of volcanism and Insular terrane is schematic. (A) modified from Kapp and Gehrels (1998); (B) digital elevation map @ 2013 Colorado Plateau Geosystems Inc.; (C) modified from Trop and Ridgway (2007). 


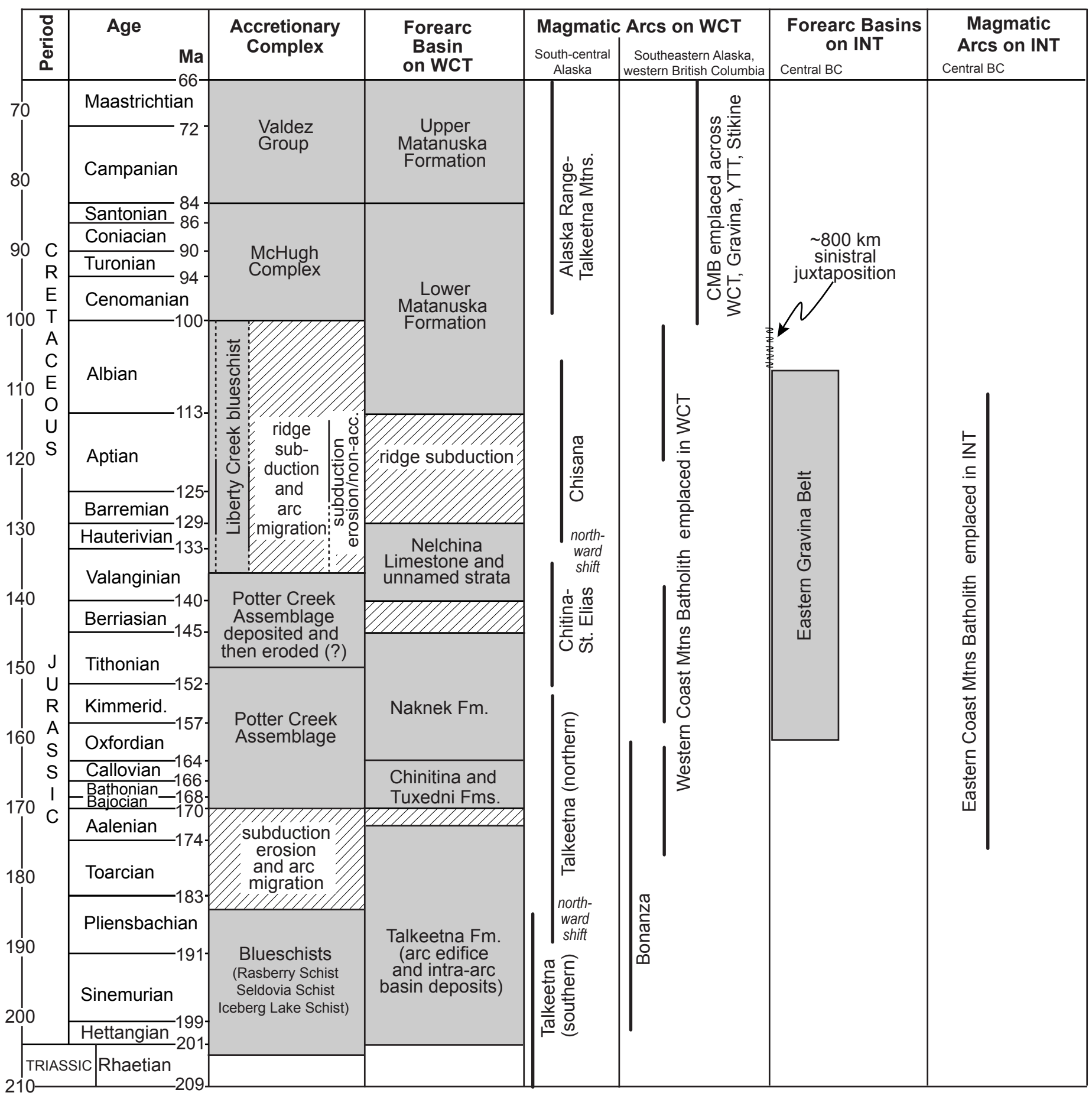

$\mathrm{Ma}$

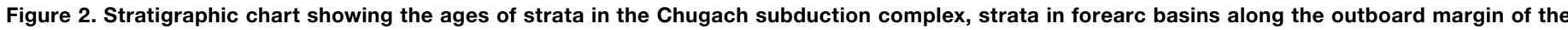

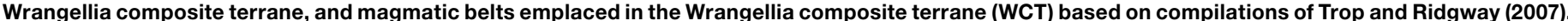

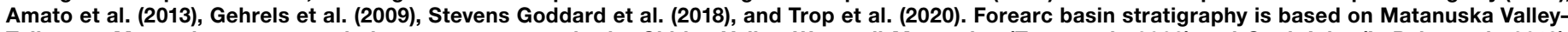

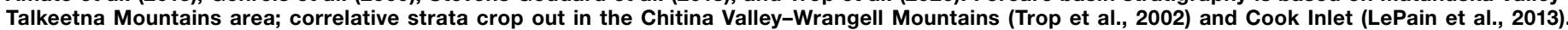
BC-British Columbia; CMB - Coast Mountains batholith; INT-Intermontane terrane; YTT-Yukon-Tanana. 
et al., 2018). Lithofacies trends and paleocurrent data support sediment flux away from the magmatic arc sources and toward the Chugach accretionary complex (Trop et al., 2002, 2005; LePain et al., 2013). Moreover, the forearc basin strata exhibit an Early Cretaceous unconformity that overlaps the age of intrusions attributed to ridge subduction along the accretionary complexforearc basin structural boundary (Trop and Ridgway, 2007; Mahar et al., 2019). In summary, both the accretionary complex and adjacent forearc basin deposits record a shared, continuous record of east-dipping subduction beneath the WCT/INS during Jurassic-Early Cretaceous time interrupted only by ridge subduction.

\section{EASTERN MARGIN OF WCT/INS: NO EVIDENCE FOR WEST-DIPPING SUBDUCTION}

SM state that we portrayed their model "as featuring only westward subduction." That was not our intent in the paper (although that is what they show in fig. 4B of Sigloch and Mihalynuk, 2017); our primary issue with the Sigloch and Mihalynuk $(2013,2017)$ model is that there is no geologic record of westward subduction beneath the WCT/INS. Some early studies considered this hypothesis in south-central Alaska (e.g., Reed and Lanphere, 1974; Wallace et al., 1989), but subsequent tectonic syntheses invoke east-dipping subduction based on regional geologic relationships (Fig. 1C; e.g., Plafker and Berg, 1994; Trop and Ridgway, 2007; Gehrels et al., 2009). SM also claim that heavy overprinting of the eastern margin of the WCT/INS prevents reconstruction of subduction polarity. We acknowledge that younger plutons, metamorphism, and structures substantially overprint segments of the margin. However, one of the reasons we focused our article on the northern Cordillera is because in that area, broad regions lack significant overprinting, and well-preserved and thoroughly studied stratigraphic successions occur intermittently along the entire inboard margin of the WCT/INS. These basinal segments provide robust constraints on the stratigraphic/detrital geochronologic connections between the WCT/INS and inboard terranes during Jurassic-Cretaceous time (Fig. 2).

We fully agree with SM that a thorough understanding of the Jurassic-Cretaceous sedimentary strata exposed along the inboard margin of the WCT/INS is a key component for determining subduction polarity during Late Jurassic and Early Cretaceous time. In the SM model, these strata represent sedimentary basins that mark the position of a continental-scale suture that defines the location of a westward subduction zone that closed the Mezcalera Ocean. The structural configuration, age, and sources of sediment for these basins, therefore, provide a rich archive that needs to be fully integrated with the new geophysical models. In contrast to the view expressed by SM that "unravelling the story of these relict basins is hampered by the huge volumes of sediment that normally clog them," we would argue that these basins provide a powerful record of the tectonic processes involved in their formation, evolution, and collapse.

In the SM model, the inboard JurassicCretaceous basins (e.g., Kahiltna, Nutzotin, Gravina basins in Figures 1A and 1B) formed above a west-dipping subduction zone in a forearc position between an oceanic arc and east-verging accretionary prism. In their interpretation, these Jurassic-Cretaceous basins formed at a stationary trench far removed from the North American continent (see fig. 4B in Sigloch and Mihalynuk, 2017), and were later accreted to North America as the westward-migrating continent was carried into the trench. Coeval with interpreted oceanic forearc basin development, the western Cordilleran margin is interpreted in the SM model as a passive margin that lacked magmatism (which is clearly incorrect). The sediment in these basins, therefore, also provides a test of the SM model, because their model predicts no Late Jurassic-Early Cretaceous magmatic activity east of the suture.

Geologic data from the Jurassic-Cretaceous sedimentary basins along this boundary from southwestern Alaska to British Columbia, however, point out several issues that bear on this problem. In southwestern Alaska, for example, there are distinctive northern (inboard) and southern (outboard) assemblages in synorogenic strata along the boundary, with the northern assemblage interpreted as being deposited in a west-facing continental forearc basin (Box et al., 2019). Sandstones from these strata have up to $50 \%$ Precambrian detrital zircon grains and also contain Cretaceous detrital zircon age probability peaks ranging from ca. 130-80 Ma. Box et al. (2019) note that these Cretaceous ages match well with the age range of widespread Mesozoic granites in the North American continental margin, rocks of the Yukon-Tanana upland (e.g., Aleinikoff et al., 2000; Dusel-Bacon et al., 2015). Similarly, parts of the Jurassic-Cretaceous strata in south-central Alaska along this boundary contain up to $30 \%$ Precambrian detrital zircons and contain common Phanerozoic detrital populations of $126 \mathrm{Ma}$, $133 \mathrm{Ma}, 147 \mathrm{Ma}$, and $172 \mathrm{Ma}$. All these detrital zircon ages can be linked to source rocks in North America, and these strata are interpreted as being deposited in a west-facing continental forearc basin setting (Trop and Ridgway, 2007; Hampton et al., 2010; Romero et al., 2020). East-dipping subduction along the continental margin inboard of these basins is recorded by ca. 120-70 Ma igneous rocks that intrude rocks of the ancestral continental margin and intermontane terrane in eastern Alaska, Yukon, and northern British Columbia (e.g., Hart et al., 2004; Mair et al., 2006; Dusel-Bacon et al., 2015). To the south, similar relations are recorded in the eastern Coast Mountains batholith of central British Columbia, which is clearly emplaced into rocks of the Stikine/Intermontane terrane and records continuous east-dipping subduction from ca. $200 \mathrm{Ma}$ to ca. $110 \mathrm{Ma}$ (Fig. 2, and lower case figs. 5 and 6 of Gehrels et al., 2009). Thus, these previous studies along the inboard margin of the boundary in Alaska and coastal British Columbia show that Jurassic-Cretaceous basins contain continental detritus indicating deposition in close proximity to North America (Fig. 1B). The detrital zircon data therefore neither support a hypothesis of a passive North American margin nor a lack of magmatism from 175 to $105 \mathrm{Ma}$ on North America, as required by the SM model.

Along the western side of these inboard basins, Jurassic-Cretaceous sedimentary strata depositionally overlie WCT/INS and yield detrital zircon signatures linked to source rocks within the WCT/INS and from magmatic rocks of ca. 200-120 Ma (e.g., Hampton et al., 2010; Lowey, 2019; Trop et al., 2020; Fasulo et al., 2020). These strata are interpreted as being deposited in an eastfacing backarc-basin setting prior to midCretaceous shortening and subaerial uplift along regional west-verging structures (Figs. $1 \mathrm{~B}$ and 1C; e.g., Manuszak et al., 2007; Hampton et al., 2010; Trop et al., 2020; Manselle et al., 2020). In summary, inboard basinal strata exposed in south-central Alaska record Jurassic-Cretaceous depositional linkages with the former continental 
margin to the east and the WCT/INS to the west, and no geologic evidence of westward subduction, such as broad assemblages of mélange and high $\mathrm{P} / \mathrm{T}$ metamorphism.

The southern continuations of these basins in southeast Alaska and coastal British Columbia record similar relations. As described by Yokelson et al. (2015), Upper Jurassic through Lower Cretaceous strata along the western margin of the basin depositionally overlie, and were derived from, the WCT/INS (western portion of Gravina basin in Fig. 1B). These relations are preserved in low-grade strata, far west of any effects of the Coast Mountains batholith. In contrast, Upper Jurassic-Lower Cretaceous strata in the eastern portion of the Gravina basin are derived from, and are interpreted to overlie, rocks of the Intermontane terrane to the east (Fig. 1B). Detailed mapping of $\sim 600 \mathrm{~km}$ of strike-length of the boundary between inboard and outboard basinal segments demonstrates that the contact is everywhere a mid-Cretaceous, west-vergent thrust fault; nowhere have any remnants of subduction, such as high-pressure metamorphism, mélange structures, or ultramafic rocks, been recognized (Yokelson et al., 2015).

Farther south, the Jurassic-Cretaceous strata of the Methow basin in southwestern Canada and northwestern Washington State are interpreted by Sigloch and Mihalynuk (2017) as a forearc basin formed above a west-dipping subduction zone separated from North America. In contrast, the basin has been interpreted as being linked to North America during JurassicCretaceous time based on several decades of geologic studies (e.g., Kleinspehn, 1985; Garver, 1992; Garver and Brandon, 1994; Garver and Scott, 1995). Many provenance studies of the Methow basin, including some using detrital zircon ages, document east-derived North American sources of sediment for this basin (e.g., DeGraaffSurpless et al., 2003; MacLaurin et al., 2011; Surpless et al., 2014).

In summary, there is no geologic evidence of Jurassic-Cretaceous basins forming as east-facing oceanic forearc basins far from North America as required by the SM model. As would be expected, these basins do have complicated histories and their paleogeographic/tectonic settings probably varied along the strike of the margin. These challenges emphasize the importance of integrating geophysics with geology.

\section{TECTONIC ANALOGS}

SM (their fig. 1) invoke a southwest Pacific analog for the tectonic setting of the northern Cordillera. Southwest Pacific analogs in various forms have been used to describe the Mesozoic Cordillera for decades (e.g., Coney, 1978; Coney et al., 1980; Silver and Smith, 1983), yet we submit that the exact analog presented by SM (their fig. 1) implies a paleogeography that is not consistent with the geologic record for the late Mesozoic time interval considered. In their model, they view all of late Mesozoic Cordilleran tectonics as a single, diachronous collision driven by arrival of an east-facing arc-trench system like the collision in progress along the northern continental margin of Australia. Although there are some geometric similarities, this modern system is significantly different from the Mesozoic Cordilleran margin. It lacks any subduction zones that dip toward Australia, and the collision in progress is an arc colliding with a passive margin - a configuration that has not existed in the Cordillera since the Paleozoic. Thus, this analog does not constitute evidence that their model is correct for the Mesozoic of the northern Cordillera.

\section{ACKNOWLEDGMENTS}

We dedicate this reply to the memory of J. Casey Moore, University of California Santa Cruz emeritus faculty member, who passed away in March 2020. His early career insights in the Kodiak Islands sections of the accretionary complex provided the framework for the many subsequent studies of this long-lived margin as well as along other modern and ancient subduction systems. His career evolved into studying modern subduction systems and included numerous collaborations with a diverse community, including hydrologists, seismologists, and petrologists. He encouraged discussion among these groups by his enthusiasm to hear their thoughts, and his "Neat!" as he listened was always sincere. We hope to emulate his positive collaborative approach as we continue to interpret ancient subduction margins. We appreciate the reviewers' careful reading of this reply and their helpful comments.

\section{REFERENCES CITED}

Aleinikoff, J.N., Farmer, G.L., Rye, R.O., and Nokleberg, W.J., 2000, Isotopic evidence for the sources of Cretaceous and Tertiary granitic rocks, eastcentral Alaska-Implications for the tectonic evolution of the Yukon-Tanana terrane: Canadian Journal of Earth Sciences, v. 37, p. 945-956, https:// doi.org /10 .1139/e00-006, https://doi.org/ 10.1139/e00-006.

Amato, J.M., Rioux, M.E., Kelemen, P.B., Gehrels, G.E., Clift, P.D., Pavlis, T.L., and Draut, A.E., 2007, U-Pb geochronology of detrital zircons and volcanic rocks from the Lower Jurassic Talkeetna Formation: Implications for the age of magmatism and inheritance in the Talkeetna Arc, in Ridgway, K.D., Trop, J.M., O’Neill, J.M., and
Glen, J.M.G., eds., Tectonic growth of a collisional continental margin: Crustal evolution of southern Alaska, Geological Society of America Special Paper 431, p. 253-271, https://doi.org/10.1130/ 2007.2431(11).

Amato, J.M., Pavlis, T.L., Clift, P.D., Kochelek, E.J., Hecker, J.P., Worthman, C.M., and Day, E.M., 2013, Architecture of the Chugach accretionary complex as revealed by detrital zircon ages and lithologic variations: Evidence for Mesozoic subduction erosion in south-central Alaska: Geological Society of America Bulletin, v. 125, p. 18911911, https://doi.org/10.1130/B30818.1.

Beranek, L.P., and Mortensen, J., 2011, The timing and provenance record of the Late Permian Klondike orogeny in northwestern Canada and arc-continent collision along western North America: Tectonics, v. 30, https://doi.org/10.1029/2010TC002849.

Blakey, R.C., and Ranney, W.D., 2018, The arrival of Wrangellia and the Nevadan orogeny: Late Triassic to Late Jurassic: ca. 240-145 Ma, in Blakey, R.C., and Ranney, W.D., eds., Ancient Landscapes of Western North America: Heidelberg, Springer, https://doi.org/10.1007/978-3-319-59636-5_7.

Box, S.E., Karl, S.M., Jones, J.V., III, Bradley, D.C., Haeussler, P.J., and O'Sullivan, P.B., 2019, Detrital zircon geochronology along a structural transect across the Kahiltna assemblage in the western Alaska Range: Implications for emplacement of the Alexander-Wrangellia-Peninsular terrane against North America: Geosphere, v. 15, p. 1774 1808, https://doi.org/10.1130/GES02060.1.

Clift, P.D., and Vannucchi, P., 2004, Controls on tectonic accretion versus erosion in subduction zones: Implications for the origin and recycling of the continental crust: Reviews of Geophysics, v. 42, RG2001, https://doi.org/10.1029/2003RG000127.

Clift, P.D., Draut, A.E., Kelemen, P.B., Bluszatajn, J., and Greene, A., 2005, Stratigraphic and geochemical evolution of an oceanic arc upper crustal section: the Jurassic Talkeetna Volcanic Formation, south-central Alaska: Geological Society of America Bulletin, v. 117, p. 902-925, https://doi.org/10.1130/B25638.1.

Coney, P.J., 1978, Mesozoic-Cenozoic Cordilleran plate tectonics, in Smith, R.B., and Eaton, G.P., eds., Cenozoic Tectonics and Regional Geophysics of the Western Cordillera, Geological Society of America Memoir 152, p. 33-50, https://doi.org/ 10.1130/MEM152-p33.

Coney, P.J., and Evenchick, C.A., 1994, Consolidation of the Cordilleras: Journal of South American Earth Sciences, v. 7, p. 241-262, https://doi.org/ 10.1016/0895-9811(94)90011-6.

Coney, P.J., Jones, D.L., and Monger, J.W.H., 1980, Cordilleran suspect terranes: Nature, v. 288, p. 329-333, https://doi.org/10.1038/288329a0.

Day, E.M., Pavlis, T.L., and Amato, J.M., 2016, Detrital zircon ages indicate an Early Cretaceous episode of blueschist facies metamorphism in southern Alaska: Implications for the Mesozoic paleogeography of the northern Cordillera: Lithosphere, v. 8, p. 451-462, https://doi.org/10.1130/ L525.1.

Decker, J., Bergman, S.C., Blodgett, R.B., Box, S.E., Bundtzen, T.K., Clough, J.G., Coonrad, W.L., Gilbert, W.G., Miller, M.L., Murphy, J.M., Robinson, M.S., and Wallace, W.K., 1994, Geology of southwestern Alaska, in Plafker, G., and Berg, H.C., eds., The Geology of Alaska: Boulder, Colorado, 
Geological Society of America, Geology of North America, v. G-1, p. 285-310.

DeGraaff-Surpless, K., Mahoney, J.B., Wooden, J.L., and McWilliams, M.O., 2003, Lithofacies control in detrital zircon provenance studies: Insights from the Cretaceous Methow basin, southern Canadian Cordillera: Geological Society of America Bulletin, v. 115, p. 899-915, https://doi .org/10.1130/B25267.1.

Dusel-Bacon, C., Hopkins, M., Mortensen, J., Dashevsky, S.S., Bressler, J.R., and Day, W., 2006, Paleozoic tectonic and metallogenic evolution of the pericratonic rocks of east-central Alaska and adjacent Yukon, in Colpron, M., and Nelson, J.L., eds., Paleozoic Evolution and Metallogeny of Pericratonic Terranes at the Ancient Pacific Margin of North America, Canadian and Alaskan Cordillera: Geological Association of Canada Special Paper 45, p. 25-74.

Dusel-Bacon, C., Aleinikoff, J.N., Day, W.C., and Mortensen, J.K., 2015, Mesozoic magmatism and timing of epigenetic $\mathrm{Pb}-\mathrm{Zn}-\mathrm{Ag}$ mineralization in the western Fortymile mining district, east-central Alaska: U-Pb zircon geochronology, whole-rock geochemistry, and $\mathrm{Pb}$ isotopes: Geosphere, v. 11, p. 786-822, https://doi.org/10.1130/GES01092.1.

Fasulo, C.R., Ridgway, K.D., and Trop, J.M., 2020, Detrital zircon geochronology and Hf isotope geochemistry of Mesozoic sedimentary basins in south-central Alaska: Insights into regional sediment transport, basin development, and tectonics along the NW Cordilleran margin: Geosphere, v. 16, https://doi.org/10.1130/GES02221.1.

Foulger, G.R., Panza, G.F., Artemieva, I.M., Bastow, I.D., Cammarano, F., Evans, J.R., Hamilton, W.B., Julian, B.R., Lustrino, M., Thybo, H., and Yanovskaya, T.B., 2013, Caveats on tomographic images: Terra Nova, v. 25, p. 259-281.

Garver, J.I., 1992, Provenance of Albian-Cenomanian rocks of the Methow and Tyaughton basins, southern British Columbia: A mid-Cretaceous link between North America and the Insular terrane: Canadian Journal of Earth Sciences, v. 29, p. 1274-1295, https://doi.org/10.1139/e92-102.

Garver, J.I., and Brandon, M.T., 1994, Fission-track ages of detrital zircons from Cretaceous strata, southern British Columbia: Implications for the Baja BC hypothesis: Tectonics, v. 13, p. 401-420, https://doi.org/10.1029/93TC02939.

Garver, J.I., and Scott, J.T., 1995, Trace elements in shale as indicators of crustal provenance and terrane accretion in the southern Canadian Cordillera: Geological Society of America Bulletin, v. 107 , p. $440-453$, https://doi.org/10.1130/0016 -7606(1995)107<0440:TEISAI>2.3.CO;2.

Gehrels, G., Rusmore, M., Woodsworth, G., Crawford, M., Andronicos, C., Hollister, L., Patchett, J., Ducea, M., Butler, R., Klepeis, K., and Davidson, C., 2009, U-Th-Pb geochronology of the Coast Mountains Batholith in north-coastal British Columbia: Constraints on age, petrogenesis, and tectonic evolution: Geological Society of America Bulletin, v. 121, p. 1341-1361, https://doi .org/10.1130/B26404.1.

Hampton, B.A., Ridgway, K.D., and Gehrels, G.E., 2010, A detrital record of Mesozoic island arc accretion and exhumation in the North American Cordillera: U-Pb geochronology of the Kahiltna basin, southern Alaska: Tectonics, v. 29, TC4015, https://doi.org/10.1029/2009TC002544.
Hart, C.J.R., Goldfarb, R.J., Lewis, L.L., and Mair, J.L., 2004, The northern Cordilleran mid-Cretaceous plutonic province: Ilmenite/magnetite-series granitoids and intrusion-related mineralization: Resource Geology, v. 54, p. 253-280, https://doi .org/10.1111/j.1751-3928.2004.tb00206.x.

Hillhouse, J.W., 1977, Paleomagnetism of the Triassic Nikolai greenstone, McCarthy quadrangle, Alaska: Canadian Journal of Earth Sciences, v. 14, p. 2578-2592, https://doi.org/10.1139/e77-223.

Hudson, T., 1979, Mesozoic plutonic belts of southern Alaska: Geology, v. 7, p. 230-234, https://doi .org/10.1130/0091-7613(1979)7<230:MPBOSA> 2.0. $\mathrm{CO} ; 2$.

Johnston, S.T., 2008, The Cordilleran ribbon continent of North America: Annual Review of Earth and Planetary Sciences, v. 36, p. 495-530, https:// doi.org/10.1146/annurev.earth.36.031207.124331.

Kapp, P.A., and Gehrels, G.E., 1998, Detrital zircon constraints on the tectonic evolution of the Gravina belt, southeastern Alaska: Canadian Journal of Earth Sciences, v. 35, p. 253-268, https://doi.org/ 10.1139/e97-110.

Kleinspehn, K.L., 1985, Cretaceous sedimentation and tectonics, Tyaughton-Methow Basin, southwestern British Columbia: Canadian Journal of Earth Sciences, v. 22, p. 154-174, https://doi.org/ 10.1139/e85-014.

LePain, D.L., Stanley, R.G., Helmold, K.P., and Shellenbaum, D.P., 2013, Geologic framework and petroleum systems of Cook Inlet basin, southcentral Alaska, in Stone, D.M., and Hite, D.M., eds., Oil and Gas Fields for the Cook Inlet Basin, Alaska: American Association of Petroleum Geologists Memoir 104, p. 37-116, https://doi.org/ 10.1306/M1041349.

Liu, L., 2014, Constraining Cretaceous subduction polarity in eastern Pacific from seismic tomography and geodynamic modeling: Geophysical Research Letters, v. 41, p. 8029-8036, https://doi .org/10.1002/2014GL061988.

Lowey, G.W., 2019, Provenance analysis of the Dezadeash Formation (Jurassic-Cretaceous), Yukon, Canada: Implications regarding a linkage between the Wrangellia composite terrane and the western margin of Laurasia: Canadian Journal of Earth Sciences, v. 56, p. 77-100, https://doi.org/ 10.1139/cjes-2017-0244.

MacLaurin, C.I., Mahoney, J.B., Haggart, J.W., Goodin, J.R., and Mustard, P.S., 2011, The Jackass Mountain Group of south-central British Columbia: Depositional setting and evolution of an Early Cretaceous deltaic complex: Canadian Journal of Earth Sciences, v. 48, p. 930-951, https://doi.org/10.1139/e11-035.

Mahar, M.A., Pavlis, T.L., Bowman, J.R., Conrad, W.K., and Goodell, P.C., 2019, Early Cretaceous ridge subduction beneath southern Alaska: Insights from zircon $\mathrm{U}-\mathrm{Pb}$ geochronology, hafnium, and oxygen isotopic compositions of the Western Chugach tonalite-trondhjemite suite: Geological Society of America Bulletin, v. 131, p. 521-546, https://doi.org/10.1130/B31918.1.

Mair, J.L., Hart, C.J.R., and Stephens, J.R., 2006, Deformation history of the northwestern Selwyn Basin, Yukon, Canada: Implications for orogen evolution and mid-Cretaceous magmatism: Geological Society of America Bulletin, v. 118, p. 304-323, https://doi.org/10.1130/B25763.1.

Manselle, P., Brueseke, M.E., Trop, J.M., Benowitz, J.A., Snyder, D.C., and Hart, W.K., 2020, Geo- chemical and stratigraphic analysis of the Chisana Formation, Wrangellia terrane, eastern Alaska: Insights into Early Cretaceous magmatism and tectonics along the northern Cordilleran margin: Tectonics, https://doi.org/10.1029/2020TC006131.

Manuszak, J.D., Ridgway, K.D., Trop, J.M., and Gehrels, G.E., 2007, Sedimentary record of the tectonic growth of a collisional continental margin: Upper Jurassic-Lower Cretaceous Nutzotin Mountains sequence, eastern Alaska Range, Alaska, in Ridgway, K.D., Trop, J.M., Glen, J.M.G., and O'Neill, J.M., eds., Tectonic Growth of a Collisional Continental Margin: Crustal Evolution of Southern Alaska: Geological Society of America Special Paper 431, p. 345-377, https:// doi.org/10.1130/2007.2431(14).

Matthews, W.A., Guest, B., Coutts, D., Bain, H., and Hubbard, S., 2017, Detrital zircons from the Nanaimo basin, Vancouver Island, British Columbia: An independent test of Late Cretaceous to Cenozoic northward translation: Tectonics, v. 36, p. 854-876, https://doi.org/10.1002/2017TC004531.

Mihalynuk, M.G., Nelson, J., and Diakow, L.J., 1994, Cache Creek terrane entrapment: Oroclinal paradox within the Canadian Cordillera: Tectonics, v. 13 , p. 575-595, https://doi.org/ 10.1029/93TC03492.

Miller, I.M., Brandon, M.T., and Hickey, L.J., 2006, Using leaf margin analysis to estimate the midCretaceous (Albian) paleolatitude of the Baja BC block: Earth and Planetary Science Letters, v. 245 , p. $95-114$, https://doi.org/10.1016/j.epsl .2006 .02 .022 .

Molnar, P., 2019, Lower mantle dynamics perceived with 50 years of hindsight from plate tectonics: Geochemistry Geophysics Geosystems, v. 20, p. 56195649, https://doi.org/10.1029/2019GC008416.

Pavlis, T.L., and Roeske, S.M., 2007, The Border Ranges fault system, southern Alaska, in Ridgway, K.D., Trop, J.M., Glen, J.M.G., and O'Neill, J.M., eds., Tectonic growth of a collisional continental margin: Crustal evolution of south-central Alaska: Geological Society of America Special Paper 431, p. 95-127, https://doi.org/10.1130/2007.2431(05).

Pavlis, T.L., Amato, J.M., Trop, J.M., Ridgway, K.D., Roeske, S.M., and Gehrels, G.E., 2019, Subduction polarity in ancient arcs: A call to integrate geology and geophysics to decipher the Mesozoic tectonic history of the northern Cordillera of North America: GSA Today, no. 11, v. 29, https:// doi.org/10.1130/GSATG402A.1.

Plafker, G., and Berg, H.C., 1994, Overview of the geology and tectonic evolution of Alaska, in Plafker, G., and Berg, H.C., eds., The Geology of Alaska: Boulder, Colorado, Geological Society of America, Geology of North America, v. G-1, p. $989-1021$.

Reed, B.L., and Lanphere, M.A., 1974, Chemical variations across the Alaska-Aleutian Range batholith: Journal of Research of the U.S. Geological Survey, v. 2, p. 343-352.

Reed, B.L., Miesch, A.T., and Lanphere, M.A., 1983, Plutonic rocks of Jurassic age in the Alaska-Aleutian range batholith: Chemical variations and polarity: Geological Society of America Bulletin, v. 94, p. 1232-1240, https://doi.org/ 10.1130/0016-7606(1983)94<1232:PROJAI > 2.0.CO;2.

Reid, M., Finzel, E.S., Enkelmann, E., and McClelland, W.C., 2018, Detrital zircon provenance of Upper Jurassic-Upper Cretaceous forearc basin 
strata on the Insular terranes, south-central Alaska, in Ingersoll, R.V., Lawton, T.F., and Graham, S.A., eds., Tectonics, Sedimentary Basins, and Provenance: A Celebration of William R. Dickinson's Career: Geological Society of America Special Paper 540, p. 571-590.

Rioux, M., Hacker, B., Mattinson, J., Kelemen, P., Blusztajn, J., and Gehrels, G., 2007, Magmatic development of an intra-oceanic arc: High-precision $\mathrm{U}-\mathrm{Pb}$ zircon and whole-rock isotopic analyses from the accreted Talkeetna arc, south-central Alaska: Geological Society of America Bulletin, v. 119, p. 1168-1184, https://doi.org/10.1130/B25964.1.

Roeske, S.M., Mattinson, J., and Armstrong, R.L., 1989, Isotopic ages of glaucophane schists on the Kodiak Islands, southern Alaska, and their implications for the Mesozoic tectonic history of the Border Ranges fault system: Geological Society of America Bulletin, v. 101, p. 1021-1037, https://doi. org/10.1130/0016-7606(1989)101<1021:IAOGSO> 2.3.CO;2.

Romero, M.C., Ridgway, K.D., and Gehrels, G.E., 2020, Geology, U/Pb geochronology, and $\mathrm{Hf}$ isotope geochemistry across the Mesozoic Alaska Range suture zone (south-central Alaska): Implications for Cordilleran collisional processes and tectonic growth of North America: Tectonics, v. 39, https://doi.org/10.1029/2019TC005946.

Sigloch, K., and Mihalynuk, M.G., 2013, Intra-oceanic subduction shaped the assembly of Cordilleran North America: Nature, v. 496, p. 50-56, https://doi.org/10.1038/nature12019.

Sigloch, K., and Mihalynuk, M.G., 2017, Mantle and geological evidence for a Late Jurassic-Cretaceous suture spanning North America: Geological Society of America Bulletin, v. 129, p. 14891520, https://doi.org/10.1130/B31529.1.

Sigloch, K., and Mihalynuk, M.G., 2020, Comment on GSA Today article by Pavlis et al., 2019: "Subduction Polarity in Ancient Arcs: A Call to Integrate Geology and Geophysics to Decipher the Mesozoic Tectonic History of the Northern
Cordillera of North America": GSA Today, v. 30, p. e47, https://doi.org/10.1130/GSATG431C.1.

Silver, E.A., and Smith, R.B., 1983, Comparison of terrane accretion in modern Southeast Asia and Mesozoic North American Cordillera: Geology, v. 11, p. 198-202, https://doi.org/10.1130/0091-7613 (1983)11<198:COTAIM>2.0.CO;2.

Stevens Goddard, A.L., Trop, J.M., and Ridgway, K.D., 2018, Detrital zircon record of a Mesozoic collisional forearc basin in south central Alaska: The tectonic transition from an oceanic to continental arc: Tectonics, v. 37, p. 529-557, https://doi .org/10.1002/2017TC004825.

Sun, D., Gurnis, M., Saleeby, J., and Helmberger, D., 2017, A dipping, thick segment of the Farallon Slab beneath central U.S.: Journal of Geophysical Research, Solid Earth, v. 122, https://doi.org/ 10.1002/2016JB013915.

Surpless, K.D., Sickmann, Z.T., and Koplitz, T.A., 2014, East-derived strata in the Methow basin record rapid mid-Cretaceous uplift of the southern Coast Mountains batholith: Canadian Journal of Earth Sciences, v. 51, p. 339-357, https://doi.org/ 10.1139/cjes-2013-0144.

Tarduno, J., Bunge, H.P., Sleep, N., and Hansen, U., 2009, The bent Hawaiian-Emperor hotspot track: Inheriting the mantle wind: Science, v. 324, p. 50-53, https://doi.org/10.1126/science.1161256.

Trop, J.M., and Ridgway, K.D., 2007, Mesozoic and Cenozoic tectonic growth of southern Alaska: A sedimentary basin perspective, in Ridgway, K.D., Trop, J.M., Glen, J.M.G., and O'Neill, J.M., eds., Tectonic Growth of a Collisional Continental Margin: Crustal Evolution of Southern Alaska: Geological Society of America Special Paper 431, p. 55-94, https://doi.org/10.1130/2007.2431(04).

Trop, J.M., Ridgway, K.D., Manuszak, J.D., and Layer, P., 2002, Mesozoic sedimentary-basin development on the allochthonous Wrangellia composite terrane, Wrangell Mountains basin, Alaska: A long-term record of terrane migration and arc construction: Geological Society of America Bulletin, v. 114, p. $693-717$, https://doi.org/10.1130/0016 -7606(2002)114<0693:MSBDOT >2.0.CO;2.

Trop, J.M., Szuch, D.A., Rioux, M., and Blodgett, R.B., 2005, Sedimentology and provenance of the Upper Jurassic Naknek Formation, Talkeetna Mountains, Alaska: Bearings on the accretionary tectonic history of the Wrangellia composite terrane: Geological Society of America Bulletin, v. 117, p. 570-588, https://doi.org/10.1130/B25575.1.

Trop, J.M., Benowitz, J.A., Koepp, D.Q., Sunderlin, D., Brueseke, M.E., Layer, P.W., and Fitzgerald, P.G., 2020, Stitch in the ditch: Nutzotin Mountains (Alaska) fluvial strata and a dike record ca. 117-114 Ma accretion of Wrangellia with western North America and initiation of the Totschunda fault: Geosphere, v. 16, p. $82-110$, https:// doi.org/10.1130/GES02127.1.

van der Meer, D.G., Spakman, W., van Hinsbergen, D.J.J., Amaru, M.L., and Torsvik, T.H., 2010, Towards absolute plate motions constrained by lower-mantle slab remnants: Nature Geoscience, https://doi.org/10.1038/ngeo708.

von Huene, R., and Scholl, D.W., 1991, Observations at convergent margins concerning sediment subduction, subduction erosion, and the growth of continental crust: Reviews of Geophysics, v. 29, p. 279-316, https://doi.org/10.1029/91RG00969.

Wallace, W.K., Hanks, C.L., and Rogers, J.F., 1989, The southern Kahiltna terrane: Implications for the tectonic evolutions of southwestern Alaska: Geological Society of America Bulletin, v. 101, p. 1389-1407, https://doi.org/10.1130/0016-7606 (1989)101<1389:TSKTIF $>2.3 . C O ; 2$.

Yokelson, I., Gehrels, G.E., Pecha, M., Giesler, D., White, C., and McClelland, W.C., 2015, U-Pb and Hf isotope analysis of detrital zircon from Mesozoic strata of the Gravina belt, southeast Alaska: Tectonics, v. 34, p. 2052-2066, https://doi.org/ $10.1002 / 2015$ TC003955.

Manuscript ReCeived 1 June 2020

ReVised MANUSCRIPT RECEIVED 10 June 2020

Manuscript accepted 13 June 2020 